\title{
A research on EU trade policy system
}

Sitong, QI, Ocean University of China, Qingdao, China 545805190@qq.com

\begin{abstract}
The EU is the world's largest trade group, occupying an important position in the world trade in goods and services, especially in the field of service trade. The EU trade in services exports and imports are higher than the United States and Japan, and the EU is the world's largest capital output and input group, and the world's largest foreign aid providers. With the deepening of the European integration process, Europe's position in the world economy and trade is on the rise. Therefore, the EU's trade policy has increasingly become the focus of attention. From the vertical point of view, research directions can be divided into trade in goods policy, trade in services policy, international direct investment policy, trade-related intellectual property policy four field. In this paper, the four vertical areas are illustrated as the focus of the study.
\end{abstract}

Keywords: EU; Policy system; Trade

JEL Classification: F2, F4, F6.

\section{Introduction}

The EU is no doubt already a "big country". At present the EU is the world's largest organization, with the highest degree of integration of economic integration. The process of European integration has greatly eliminated the regional division of resource resources and the lack of resource endowments, thus effectively reducing the risk of external dependence on resources (Bollen et al., 2016). The influence of the euro on the international monetary system has gradually emerged, so that the status of the EU in the world economy has been further improved. Eastward expansion further strengthens the EU's position in the world economy. The EU is the world's largest trade group, occupying an important position in the world trade in goods and services, especially in the field of service trade. Whether the EU trade in services exports or imports are higher 
than the United States and Japan, and the EU is the world's largest capital output and input group, and the world's largest foreign aid providers (Burns, 2017). While the economic strength and trade strength are expanding, the ability of the EU to participate in the development of world economic rules is also growing. With the deepening of the European integration process, Europe's position in the world economy and trade is on the rise. Therefore, the EU's trade policy has increasingly become the focus of attention. It can be said that trade policy is not just an economic issue, but also a political issue, a legal issue. The researchers argue very intensely about the scope of the design of trade policy. Typically, in multilateral trade negotiations, the definition of trade policy involves a multiparty game that involves economic, political, and other considerations (Jūratè, 2015). However, an indisputable fact is that, in line with the expansion of trade concepts, trade policy coverage is not limited to border measures, but also to trade-related domestic policies and measures. According to WTO rules, trade policy focuses on trade-related policy measures, including trade in goods and services, trade-related investment policies, and trade-related IP policies (Ellerman et al., 2015). Moreover, with the deepening development of the multilateral trading system, new issues are being introduced, and trade policy will also involve investment policy, competition policy, environmental policy, labor policy and other fields. The research on the framework of the EU's trade policy is fruitful, involving systematic research on single-market policies and foreign trade policies, as well as specialized research on sub-sectors and subsectors.

\section{EU trade policy system}

For the EU trade policy system, the trade here is a unified concept, which can be divided into three levels: one is the trade activities within the member countries, the other is the "internal trade" between the member states, and the third is the "foreign trade" between member countries and third countries. As a result of the customs union and the common market, the trade relations among member states have lifted all tariffs, quantitative restrictions and any other forms of trade barriers, forming an internal trade relationship between the single tariff area and the common market (Poletti, 2016). Foreign trade policies and measures such as tariffs, non-tariff measures, international agreements and other general trade policies are only applicable in trade relations with third countries.

The EU's unified trade policy can be divided into internal trade policy and foreign trade policy. The internal trade policy of the Community aims to promote 
the free movement of goods, persons, services and capital between member States. In terms of foreign trade, given the dependence on trade, the EC generally advocates free trade policy. But the EU trade policy to protect the internal market is also very obvious, including the common agricultural policy, anti-dumping and other trade measures, as well as a series of tariffs, non-tariff measures. At the same time, EU trade policy is also an important part of its foreign policy. In the EU's political, economic, cultural and military external activities, trade is an extremely important aspect (Garcia-Duran et al., 2016). Therefore, the EU's overall policy of foreign policy is also bound to be reflected in its trade policy.

The EU trade policy system can be viewed and studied from different perspectives, and different perspectives mean different research priorities. From the horizontal point of view, research directions can be divided into multilateral, regional, bilateral, internal four levels; from the vertical point of view, research directions can be divided into trade in goods policy, trade in services policy, international direct investment policy, trade-related intellectual property policy four field (Ruf, 2017). In the following, the four vertical areas will serve as the focus of the study. As we all know, the WTO legal system divides trade policy into trade in goods, trade in services, trade-related investment measures, and traderelated intellectual property measures. The EU trade policy system is different from the WTO. But it can be seen that the division of the EU policy system is basically based on the WTO, because the EU as a member of the WTO, its trade policy is bound to be more and more affected by the WTO and constraints, which is reflected in the development of the EU trade policy system (Burmeister, 2016). The only difference is that the third area of the EU trade policy system is the policy of international direct investment, not just trade-related investment measures. The drafting of the European Constitutional Treaty, adopted unanimously by the EU Constituent Assembly, expands the scope of the common trade policy, which clearly includes trade in goods, trade in services, traderelated intellectual property and international direct investment into Common trade policy.

\section{EU trade system in goods}

The trade policy of goods mainly includes import management policies, export management policies and other policies that affect trade in goods. The EU trade policy mainly includes both common trade policies and common agricultural policies and derived secondary legislation. Among them, for the 
customs union and common trade policy and its derived legislation, the EC has exclusive power. The EC's foreign trade policy on agricultural products is mainly determined in the framework of the common agricultural policy and is part of the policy of change and is therefore not subject to the common trade policy of the EC (Fujjiwara, 2016).

\subsection{Trade Policy of Goods in Common Trade Policy}

The policies related to the trade policy of goods derived from the common trade policy mainly include: common external tariff, common customs tariff, origin system, customs valuation system, common import and export system, protection of trade measures (anti-dumping, countervailing, safeguard measures), "New trade policy measures" (including market access strategy and trade barriers survey system) and so on.

\subsection{Common Agricultural Policy and Trade in Agricultural Products}

The common agricultural policy is an important policy that began to be implemented with the customs union when the European Economic Community was established. It was the most successful and most problematic area in the process of economic integration. EU agencies have more authority over common agricultural policies than others, and guidelines are set out for policies or measures implemented by Member States (Wiemann, 2016).

\section{EU trade in services policy system}

Service trade in the expansion of the border movement is shown in types of the personnel, capital, and information flow. The management of trade in services is often carried out in the form of domestic legislation or in the form of domestic regulations. The policy of trade in services can be divided into policies on national policy and national treatment, including domestic taxation, enterprise form requirements, equity requirements, quantity requirements, regional restrictions, natural person mobility policy, term requirements, eligibility requirements, business restrictions, etc (Munaretto, 2015). EU external service trade policy coordination in general maintained with development of its internal policy. Many industry management regulations are mostly involved in both internal and external aspects. The EU insists on the limited principle of internal trade liberalization, but also attaches great importance to harmonization with the multilateral trading system while building an internal single service market. 


\section{Intellectual Property Trade Policy}

Intellectual property refers to the combination of ideas, inventions and creative expressions that give the status of property by public will. Intellectual property policy mainly covers copyright, trademark, geographical indication and origin, industrial design, patents, new varieties of plants, integrated circuit layout design, undisclosed information. The enforcement measures of intellectual property rights include civil litigation and relief procedures, temporary protection measures, administrative relief procedures, customs special border measures, and criminal procedures for infringement of punishment. There are many reasons why intellectual property has become a trade issue (mainly counterfeit goods trade), of which the most fundamental is the rapid development of international trade in goods containing intellectual property rights (Perišin, 2015). And many industrialized countries have come to realize that the lack of protection of intellectual property by technology-importing countries has reduced their competitive advantage in high-tech fields. Thus, despite the long delays in the trade of counterfeit goods, commodity trade with plagiarized intellectual property is becoming increasingly controversial as the replication technology is more advanced and the replication of intellectual property is easier and cheaper.

\section{Foreign Direct Investment Policy}

Trade-related investment measures are policies that are used to encourage foreign investors to acquire certain performance standards. The power of the EU in the field of foreign direct investment policy is gradually increasing. According to the Treaty of the European Union, the free flow of capital has become an important goal of the community, and the capital control between EU member states and between member countries and third countries has been gradually relaxed. Article 56-60 of the EC Treaty provides stipulation for freedom of movement and freedom of movement of capital. In particular, article 56 provides stipulation for the prohibition of all restrictions on capital flows and payments between all Member States and between Member States and third States. Restrictive measures can only be implemented in exceptional circumstances, such as when there are serious difficulties in the operation of the monetary union (article 59) and difficulties in the event of a balance of payments (arts. 119 and 120). 


\section{Conclusion}

With the extension of the connotation of trade and its extension, foreign trade and domestic trade are gradually combined. From the trade itself, it is an integral part of economic activity. There is no essential difference between foreign trade and domestic trade. Trade should be a unified concept. Under open economic conditions, foreign trade and domestic trade are more difficult to distinguish absolutely, especially when it comes to trade policy, this distinction is even more difficult.

\section{References:}

[1] Bollen, Yelter, F. D. Ville, and J. Orbie. "EU trade policy: persistent liberalisation, contentious protectionism." Journal of European Integration 38.3(2016):279-294.

[2] Burns, William C. G. "The European Union's Emissions Trading System: Climate Policymaking Model, or Muddle? (Part 1) Title]." Social Science Electronic Publishing (2017).

[3] Jūratė Jaraitè-Kažukauskè, and A. Kažukauskas. "Do Transaction Costs Influence Firm Trading Behaviour in the European Emissions Trading System?." Environmental \& Resource Economics 62.3(2015):583-613.

[4] Ellerman, A. Denny, C. Marcantonini, and A. Zaklan. "The European Union Emissions Trading System: Ten Years and Counting." Review of Environmental Economics \& Policy 10.1(2015):rev014.

[5] Poletti, Arlo, D. D. Bièvre, and M. Hanegraaff. "WTO Judicial Politics and EU Trade Policy: Business Associations as Vessels of Special Interest?." British Journal of Politics \& International Relations 18.1(2016):págs. 196-215.

[6] Garcia-Duran, Patricia, M. Millet, and J. Orbie. EU Trade Policy Reaction to the BIC: From Accommodation to Entrenchment. EU Policy Responses to a Shifting Multilateral System. Palgrave Macmillan UK, 2016.

[7] Ruf, and J. Anna. "A policy analysis of the EU Emissions Trading System and its crisis." Ipe Working Papers (2017).

[8] Burmeister, Johannes, and S. Peterson. "National climate policies in times of the European Union Emissions Trading System (EU ETS)." Kiel Working Papers (2016).

[9] Fujjiwara, Noriko. "Policy Interaction between the EU Emissions Trading System and the Renewable Energy Directive." Social Science Electronic Publishing (2016).

[10] Wiemann, Jürgen. "EU trade policy towards developing countries: is it coherent with development goals?." (2016).

[11] Munaretto, S, and H. Walz. "A policy exercise on the future of the EU Emission Trading System, Workshop report. CECILIA2050 project report." None (2015).

[12] Perišin, Tamara. "EU Regulatory Policy and World Trade." European Constitutional Law Review 11.1(2015):99-120. 